\title{
Transformation of the rheological properties of a soya oil-in-water emulsion as a result of the addition of salt substitutes
}

\author{
SEPPO LAHTINEN \\ Department of Food Chemistry and Technology, University of Helsinki, \\ SF-00710 HELSINKI, Finland
}

\begin{abstract}
The influences of $1.00 \%$ wt/wt $\mathrm{NaCl}$, Morton Lite Salt (50 \% wt/wt $\mathrm{NaCl}$ and $50 \% \mathrm{KCl})$ and Mineral Salt $\left(65 \% \mathrm{NaCl}, 25 \% \mathrm{KCl}\right.$ and $\left.10 \% \mathrm{MgSO}_{4} \cdot 7 \mathrm{H}_{2} \mathrm{O}\right)$ on the rheological properties of an emulsion containing 1.0\% sodium alginate, $1.0 \%$ acetylated distarch adipate, $68 \%$ water and $30 \%$ oil were compared at a pH value 4.5 by means of a coaxial cylinder viscometer. An empirical model composed of two exponential terms was used to describe the rheological behavior under a constant shear rate. The addition of any of the three salts increased the essential mechanical parameter values remarkably. The influences of Morton Lite Salt and Mineral Salt were quite similar and different from that of $\mathrm{NaCl}$. When xanthan gum replaced sodium alginate in the emulsion, small decreases were observed in some of the parameter values owing to salt addition. No differences existed between the influences of salts in that case.
\end{abstract}

Index words: emulsions, rheological properties, sodium chloride, salt substitutes, alginates, xanthan gum

\section{Introduction}

Few systematical studies exist concerning the influences of inorganic salts on macromolecular compounds in an emulsion system. In general, stability, as well as rheological alterations, arise either because of the association of counterions with the polymer molecules or, partially, through influences on the structure and properties of the solvent (SABHARWAL and VAKaleris 1972, VAKaleris and Sabharwal 1972, Mita et al. 1974, Lata et al. 1977, Stone and Campbell 1980, Ver.
NON CARTER and SHeRmAn 1980, 1981a, 1981b, Rivas and SHerman 1983, 1984). Modification of stability or the rheological properties of some protein-stabilized emulsions is possible, by the substitution of other cations for sodium (LAHTINEN and PAalanen 1982, LAHTINEN 1987). In this paper, the results arising from partial $\mathrm{NaCl}$ substitution in model emulsions containing starch and either sodium alginate or xanthan gum are presented. 


\section{Materials and methods}

The roughened MV I P coaxial cylinder assembly of Haake Rotovisco RV3 viscometer was used in the measurements. The emulsion samples were prepared similarly and the startshear experiment procedure was similar to that described earlier (LAHTINEN 1987). The shear rate $\dot{\gamma}$ was constant $4.68 \mathrm{~s}^{-1}$, roughly corresponding to the stimuli associated with the sensory evaluation of textural properties of liquid foods (CuTLer et al. 1983, KIOSSEOGLOU and Sherman 1983). The measurement time was 5.0 minutes. Duplicate samples of each kind were prepared and three measurements were taken from each of them to obtain representative material for one-way analysis of variance and Tukey's test.

The empirical models (1) through (3) where $\mathrm{G}^{*}$ is the modulus of deformation over the linear part of the stress-time curve (LAHTINEN 1987), $\eta_{\mathrm{i}}$ is the empirical coefficient of the i:th exponential term and $\lambda_{i}$ is the corresponding time constant were fitted to the data. Paired time $(\mathrm{t})$ and shear stress $(\tau)$ values were collected for this purpose at intervals of two or ten seconds, depending on the rate of change of the shear stress. The same instants were used in every fitting. In practice, the

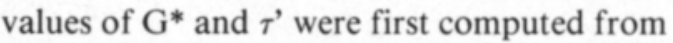
the recorded curve. The standard error of estimate of $\tau \mathrm{s}_{r,}$, was then minimized with a computer to produce the parameter values in Eq. (2).

$$
\begin{array}{ll}
\tau=\mathrm{G}^{*} \dot{\mathrm{t}} & \mathrm{t} \leq \mathrm{t}^{\prime} \\
\tau-\tau^{\prime}=\dot{\gamma} \sum_{\mathrm{i}=1}^{\mathrm{n}} \eta_{i}\left[1-\mathrm{e}^{\left(\mathrm{t}^{\prime}-\mathrm{t}\right) / \lambda_{\mathrm{i}}}\right] & \mathrm{t} \geq \mathrm{t}^{\prime} \\
\mathrm{t}^{\prime}=\frac{\tau^{\prime}}{\mathrm{G}^{*} \dot{\gamma}} &
\end{array}
$$

The salt substitute mixtures were similar to Morton Lite Salt (50 \% wt/wt NaCl and $50 \%$ $\mathrm{KCl})$ and Mineral Salt $(65 \% \mathrm{NaCl}, 25 \% \mathrm{KCl}$ and $\left.10 \% \mathrm{MgSO}_{4} \cdot 7 \mathrm{H}_{2} \mathrm{O}\right)$. The basic emulsion contained $1.0 \% \mathrm{wt} / \mathrm{wt}$ sodium alginate (Manucol DH, Kelco International Ltd), $1.0 \%$ acetylated distarch adipate (Instant Clearjel, Laing National Ltd), $68 \%$ ionexchanged water and $30 \%$ soybean oil. The
$\mathrm{pH}$ value of the basic emulsion was 4.5 and the salt concentration of the samples was $1.00 \%$ wt/wt. The experiments were also accomplished with another emulsion that contained $0.5 \%$ xanthan gum (Keltrol, Kelco Division of Merck, Inc.) and $0.5 \%$ more water instead of the $1.0 \%$ concentration of alginate. The same $\mathrm{pH}$ value and salt concentration as above were used in this latter type of emulsion.

In order to compare the influence of salts in an emulsion with that in water, apparent viscosities of either $1.4 \% \mathrm{wt} / \mathrm{wt}$ sodium alginate or $1.4 \%$ both alginate and starch were measured in ion-exchanged water once at shear rate values $37.44 \mathrm{~s}^{-1}$ and $26.44 \mathrm{~s}^{-1}$, respectively. Measurements were taken from similar samples after the addition of $1.4 \%$ wt/wt $\mathrm{NaCl}$ or Morton Lite Salt, too. The salt or polysaccharide concentration of $1.4 \%$ approximately corresponded to those in the continuous phase of the emulsions. The MV I assembly that has smooth surfaces was used in these measurements. The samples were allowed to stand overnight before measurements were taken.

The ingredients sodium alginate and xanthan gum were used in the maximum concentrations allowed by the Finnish legislation. These ingredients were chosen because of their wide use in emulsions and because their polyionic nature makes them suspectible to the influences of salts. Acetylated distarch adipate was included for practical reasons for thickening and because it was observed to maintain its normal viscosity over the range of salt concentrations that was used. This ability was confirmed in preliminary experiments on its water dispersions by using starch in concentrations between $1.0 \%$ and $3.0 \%$, and $\mathrm{a} \mathrm{NaCl}$ concentration of $1.4 \%$. The $\mathrm{pH}$ value of these dispersion was 4.5 , as it was in all experiments in this study.

\section{Results and discussion}

All the emulsion samples exhibited a behavior characteristic to viscoelastic mate- 
Table 1. Means of the parameters describing the curves of the emulsion containing sodium alginate.

\begin{tabular}{lccccccc}
\hline & $\begin{array}{c}\mathrm{G}^{*} \\
\mathrm{~N} / \mathrm{m}^{2}\end{array}$ & $\begin{array}{c}\tau^{\prime} \\
\mathrm{N} / \mathrm{m}^{2}\end{array}$ & $\begin{array}{c}\eta_{1} \\
(\mathrm{~N} \mathrm{~s}) / \mathrm{m}^{2}\end{array}$ & $\begin{array}{c}\lambda_{1} \\
\mathrm{~s}\end{array}$ & $\begin{array}{c}\eta_{2} \\
(\mathrm{~N} \mathrm{~s}) / \mathrm{m}^{2}\end{array}$ & $\begin{array}{c}\lambda_{2} \\
\mathrm{~s}\end{array}$ & $\begin{array}{c}s_{+, \cdot t} \\
\mathrm{~N} / \mathrm{m}^{2}\end{array}$ \\
\hline $\mathrm{No}$ salt & 0.08 & 1.4 & 0.28 & 5.7 & 0.16 & 135 & 0.02 \\
$\mathrm{NaCl}$ & 0.30 & 8.5 & 0.79 & 3.9 & 0.14 & 4.5 & 0.07 \\
Morton Salt & 0.28 & 7.3 & 1.16 & 5.3 & 0.50 & 92 & 0.06 \\
Mineral Salt & 0.28 & 7.5 & 1.08 & 5.6 & 0.45 & 74 & 0.06 \\
\hline Least significant & & & & & & & \\
difference (p $\leq 0.05)$ & 0.03 & 1.4 & 0.23 & 1.3 & 0.09 & 46 \\
\hline
\end{tabular}

rials that do not show structural breakdown (Elliott and Ganz 1971). A clear difference existed between the samples containing no added salt and the other samples in the emulsion that contained alginate, for the $\mathrm{G}^{*}, \tau^{\prime}$, $\eta_{1}$ and, in the case of the salt substitutes, $\eta_{2}$ values were clearly higher in the latter ones (Table 1). In addition, the influence of $\mathrm{NaCl}$ was distinctly different from that of the salt substitutes in this emulsion. In fact, only one exponential term would had been needed for the rheological characterization of the behavior obtained with $\mathrm{NaCl}$ instead of the two used (Table 1). Two exponential terms did not

Table 2. Influence of salts on apparent viscosities of the polysaccharides in water.

\begin{tabular}{lcc}
\hline Salt type & \multicolumn{2}{c}{ Apparent viscosity $\times 10^{3}$} \\
\cline { 2 - 3 } & $\begin{array}{c}\text { Alginate } \\
(\mathrm{N} \mathrm{s}) / \mathrm{m}^{2}\end{array}$ & $\begin{array}{c}\text { Alginate \& starch } \\
(\mathrm{N} \mathrm{s}) / \mathrm{m}^{2}\end{array}$ \\
\hline No salt & 15.3 & 54.8 \\
$\mathrm{NaCl}$ & 14.5 & 47.4 \\
Morton Salt & - & 48.5 \\
\hline
\end{tabular}

produce a lower standard error value than one term did. The first difference is important because it means that a structurizing mechanism associated with the behavior of starch and/or alginate molecules expressly at the oil-in-water interface governed the formation of the rheological properties. This becomes evident when we see that both the sodium alginate as such and in combination with the starch exhibited a slight decrease in apparent viscosity after the addition of $1.4 \%$ of $\mathrm{NaCl}$ (Table 2). Such a decrease is a common property of many polysaccharides in water solution because of a reduction in the extent of hydration of their molecules (Pomeranz 1985). It has also been reported to occur in an emulsion stabilized by mesquite gum (VERNON Carter and Sherman 1980). It is thus noteworthy that in the other emulsion that was otherwise similar but contained $0.5 \%$ xanthan gum instead of alginate, small decreases were observed in some of the parameter values owing to salt addition (Table 3). However, no significant differences existed between the influences of salts in that case.

Table 3. Means of the parameters describing the curves of the emulsion containing xanthan gum.

\begin{tabular}{lcccccrr}
\hline & $\begin{array}{c}\mathrm{G}^{*} \\
\mathrm{~N} / \mathrm{m}^{2}\end{array}$ & $\begin{array}{c}\tau^{\prime} \\
\mathrm{N} / \mathrm{m}^{2}\end{array}$ & $\begin{array}{c}\eta_{1} \\
(\mathrm{~N} \mathrm{~s}) / \mathrm{m}^{2}\end{array}$ & $\begin{array}{c}\lambda_{1} \\
\mathrm{~s}\end{array}$ & $\begin{array}{c}\eta_{2} \\
(\mathrm{~N} \mathrm{~s}) / \mathrm{m}^{2}\end{array}$ & $\begin{array}{c}\lambda_{2} \\
\mathrm{~s}\end{array}$ & $\begin{array}{c}\mathrm{s}_{r \cdot 1} \\
\mathrm{~N} / \mathrm{m}^{2}\end{array}$ \\
\hline No salt & 0.17 & 5.5 & 0.85 & 5.3 & 0.38 & 100 & 0.05 \\
$\mathrm{NaCl}$ & 0.15 & 3.8 & 0.73 & 5.8 & 0.35 & 37 & 0.05 \\
Morton Salt & 0.17 & 3.8 & 0.70 & 5.2 & 0.38 & 37 & 0.04 \\
Mineral Salt & 0.17 & 3.6 & 0.82 & 5.5 & 0.36 & 35 & 0.04 \\
\hline Least significant & & & & & & & 37 \\
difference $(\mathrm{p} \leq 0.05)$ & n.s. & 0.7 & 0.14 & n.s. & n.s. & & \\
\hline
\end{tabular}

n.s. - not significant. 
There was no difference between the influences of the salt substitutes in the emulsion that contained alginate (Table 1). This fact, as well as their different influence in this emulsion when compared with that of $\mathrm{NaCl}$, is best explained by the more difficult association of sodium and magnesium in relation to potassium ions with the polymer molecules. The potassium ion with its smallest hydration radius is able to approach most closely the negative site attachment on a macromolecule. Hence, it will be held most strongly according to Coulomb law. This property probably led to alterations in the physical structure of the emulsion, perhaps through the medium of multiplied interfacial formation of hydrogen bonds between adjacent drops covered by the hydrocolloid film (VERNON CARTER and SHer-

\section{References}

Cutler, A.N., Morris, E.R. \& TAYlor, L.J. 1983. Oral perception of viscosity in fluid foods and model systems. J. Texture Studies 14: 377-395.

EllıotT, J.H. \& GANZ, A.J. 1971. Modification of food characteristics with cellulose hydrocolloids. I. Rheological characterization of an organoleptic property (unctuousness). J. Texture Studies 2: 220-229.

Kiosseoglou, V.D. \& Sherman, P. 1983. The rheological conditions associated with judgement of pourability and spreadability of salad dressings. J. Texture Studies 14: 277-282.

LAHTINEN, S. 1987. A dynamic analysis model for stress decay in emulsions under steady shear rate. Accepted for publication in Lebensmittelwissenschaft und -Technologie.

— \& PaAlanen, L. 1982. Effect of three-component dietary salts on the coalescence of protein stabilized emulsions. Finn. Chem. Lett. 1982, 1-2: 22-24.

Lata, P., Sharma, M.K. \& Jain, S.P. 1977. Electrolyte flocculation of haemoglobin-stabilized toluene/water emulsion. Indian J. Chem., Sect. A 15: 958-961.

Mita, T., Iguchi, E., Yamada, K., Matsumoto, S. \& Yonezawa, D. 1974. Dispersion state of proteinstabilized emulsions. II. Effect of sodium chloride on stability of oil-in-water systems. J. Texture Studies 5: 89-96.

Pomeranz, Y. 1985. Functional Properties of Food Components. p. 96. Academic Press, Inc., Orlando.

Rivas, H.J. \& Sherman, P. 1983. Soy and meat proteins as food emulsion stabilizers. 2. Influence of emulsifi-
MAN 1981b). The influence of magnesium and sulphate ions was small because of their large size and low concentration.

It is possible that the somewhat smaller reducing influence of the salt substitutes on the extent of hydration of macromolecules played a role in the formation of the difference between $\mathrm{NaCl}$ and the salt substitutes, too. This influence originates from the lower total amount of ions in the salt substitutes compared with that in equal masses of $\mathrm{NaCl}$. However, the increase in apparent viscosity of the alginate-starch dispersion was negligible after the addition of $1.4 \%$ Morton Lite Salt instead of $\mathrm{NaCl}$ (Table 2). It remains to be seen whether such difference has an importance in this type of emulsions. The above results do not support it. cation temperature, $\mathrm{NaCl}$ and methanol on the viscoelastic properties of corn oil-in-water emulsions incorporating acid precipitated soy protein. J. Texture Studies 14: 267-275.

- \& Sherman, P. 1984. Soy and meat proteins as food emulsion stabilizers. 4 . The stability and interfacial rheology of $\mathrm{o} / \mathrm{w}$ emulsions stabilized by soy and meat protein fractions. Colloids Surf. 11: 155-171.

Sabharwal, K. \& Vakaleris, D.G. 1972. Stability of fluid food emulsions. I. Effects of emulsifiers, electrolytes and sodium caseinate. J. Dairy Sci. 55: 277-282.

Stone, M.B. \& Campbell, A.M. 1980. Emulsification in systems containing soy protein isolates, salt and starch. J. Food Sci. 45: 1713-1716.

VaKaleris, D.G. \& Sabharwal, K. 1972. Stability of fluid food emulsions. II. Interacting effect of electrolytes, sodium caseinate and emulsifiers. J. Dairy Sci. 55: 283-288.

Vernon Carter, E.J. \& Sherman, P. 1980. Rheological properties and applications of mesquite tree (Prosopis juliflora) gum. 2. Rheological properties and stability of $\mathrm{o} / \mathrm{w}$ emulsions containing mesquite gum. J. Texture Studies 11: 351-365.

- \& Sherman, P. 1981a. Rheological properties and applications of mesquite tree (Prosopis juliflora) gum. 3. The influence of mesquite gum on the interfacial tension between oil and water. J. Disp. Sci. Technol. 2: $381-397$. 
- \& Sherman, P. 1981b. Rheological properties and applications of mesquite tree (Prosopis juliflora) gum.

4. Rheological properties of mesquite gum films at the

\section{SELOSTUS}

Erään soijaöljy vedessä -emulsion reologisten ominaisuuksien muuttuminen $\mathrm{NaCl}$ :n korvaavien suolojen lisäyksen seurauksena

\section{Seppo Lahtinen}

Helsingin yliopisto, Elintarvikekemian ja -teknologian laitos, 00710 Helsinki

$\mathrm{NaCl}: \mathrm{n}$, Mortonsuolan (Morton Lite Salt) ja Mineraalisuolan $1.00 \mathrm{p}-\%$ pitoisuuden vaikutuksia $1.0 \%$ natriumalginaattia, $1.0 \%$ asetyloitua ditärkkelysadipaattia, $68 \%$ vettă ja $30 \%$ óljyă sisăltăneen emulsion reologisiin ominaisuuksiin verrattiin koaksiaalisylinteriviskometrin avulla pH:ssa 4.5. Mortonsuola sisältaaả 50 p- $\%$ NaCl:a ja $50 \%$ $\mathrm{KCl}$ :a ja Mineraalisuola vastaavasti $65 \% \mathrm{NaCl}: \mathrm{a}, 25 \%$ $\mathrm{KCl}$ :a ja $10 \% \mathrm{MgSO}_{4} \cdot 7 \mathrm{H}_{2} \mathrm{O}$ :a. Kahdesta eksponentiaalisesta termistă koostettua empiiristă mallia kăytettiin kuvaamaan emulsion reologista käyttăytymistă vakion oil-in-water interface. J. Disp. Sci. Technol. 2: $399-413$.

Ms received October 30, 1986 leikkausnopeuden alaisena. Mallin keskeisten mekaanisten parametrien arvot kasvoivat huomattavasti lisăttăessă mită tahansa kyseisistă kolmesta suolasta emulsioon. Mortonsuolan ja Mineraalisuolan vaikutukset olivat keskenăăn varsin samanlaiset, ja ne poikkesivat $\mathrm{NaCl}$ :n vaikutuksesta. Kun natriumalginaatti korvattiin ksantaanikumilla, emulsion joidenkin parametrien arvojen havaittiin hieman pienenevăn suolan lisăyksen seurauksena. Suolojen vaikutusten vălillă ei siină tapauksessa ollut eroja. 